\title{
The IFRS as Tax Base: Potential Impact on a Small Open Economy
}

\author{
David Procházka*
}

\section{Introduction}

Regulation (EC) 1606/2002 on International Accounting Standards was approved as an outcome of accounting harmonisation efforts within the European Union. As unintended effect, the adoption of IFRS influences tax systems, as many countries oblige or allow companies to apply the IFRS in their individual financial statements too. Governments are forced to decide whether, and in which way, companies preparing their statutory accounts under IFRS regime shall reflect the IFRS based figures when calculating their income tax duty. The IFRS can possess decision-usefulness not only for financial reporting purposes, but it may also be an alternative tool of tax policies. Introducing the IFRS, as a tax base may be an attractive option for public budgets of small open economies, which struggle to offer favourable economic environment.

On the other hand, the switch to IFRS for taxation purposes may significantly influence tax revenues. The discussion about advantages and disadvantages, provided that IFRS were applied for taxation purposes, is lively in countries with a relatively high level of book-tax conformity (i.e. with a tight link between accounting and taxation). The changes in corporate reporting influences tax expense immediately, thus the risks stemming from the potential switch to IFRS-based taxation are assessed extensively. Moreover, as the IFRS are prepared by an independent body, the stability and predictability of taxes may be out of control of policy makers, which might serve as argument against using the IFRS as the starting point for taxation.

\footnotetext{
\# This article has been prepared under the research project Assumptions for Introduction of the IFRS as an Alternative Tax Base in a Small Open Economy: Evaluation of Its Impact on Country's Competitiveness supported by the Czech Science Foundation under the registration number P403/12/1901.

Ing. David Procházka, Ph.D. - Senior Lecturer; Department of Financial Accounting and Auditing, Faculty of Finance and Accounting, University of Economics, W. Churchill Sq. 4, Prague, 130 67, Email: <prochazd@vse.cz>.
} 
The topic is, therefore, rather political than economic. However, the decision whether to allow or not the IFRS to be a tax base should be grounded on at least some sound economic arguments. A proper analysis should evaluate the impact of "IFRS taxation" complexly, taking into account all potential benefits and costs from the perspective of companies, tax administrator and national economy. A comprehensive qualitative inspection is relatively easily feasible for all three levels, but a quantitative analysis is difficult, especially on national economy level. Allowing IFRS to be a tax base would influence not only fiscal revenues, but also it can have other unintentional macroeconomic effects. Following the concept of comparative advantages (Ricardo 1817), the change in tax policy may e.g. attract more foreign direct investments (Procházka and Procházková Ilinitchi 2011), can cause the shift of jurisdiction of multinational firms (Gordon and MacKie-Mason 1995) or may decrease incentives to tax optimisation (Heckemeyer and Overesch 2013). To measure the total macroeconomic impact of change in rules for taxable profits would require the construction of mutual relations among all economic parameters affected, based e.g. on Walrasian equations of general equilibrium, which is practically unattainable.

For the reasons outlined above, the paper's scope is restricted and it investigates the effects on companies only. The paper presents some empirical data on corporate income tax in the Czech Republic, with focus on listed companies. Czech listed companies are obliged to apply the IFRS in their statutory accounts, but they are not allowed to use the IFRS for taxation. The paper attempts at sketching a hypothetical situation, what it would happen, if the IFRS were applicable also for corporate income tax calculations. More precisely, we assess the share of IFRS companies on total tax revenues and scrutinise, whether the choice of different level of accounting income (excluding or including Other Comprehensive Income) would influence tax collection significantly. The quantitative analysis of current tax expenses may uncover potential risks from the change in taxation regime. To meet this goal, the paper is organised as follows. The next chapter reviews the literature relevant to the issues and develops the fundamental hypotheses and methodology for their empirical testing. Further, the results of empirical analysis are presented and discussed. The final chapter summarises the main findings and limitations of the study and suggests further streams of research in the field. 


\section{Background and Methodology}

Introducing the IFRS as a proper basis for taxation is the subject of a rich and stormy debate, prominently in German-speaking countries, which are characterised by a deep level of tax-accounting dependence. However, the authors not only deal not only with local perspectives, but also in international context (Oestreicher and Spengel 2007). Following Regulation (EC) 1606/2002 and first mentions on potential consolidation of corporate taxes, theoretical arguments in favour and against an alternative system of accounting standards relevant for corporate taxation have been discussed. A comprehensive overview of relevant literature analysing all advantages and disadvantages can be found in (Eberhartinger and Klostermann 2007). There are several studies, which try to assess the quantitative effects on taxation, should IFRS be used for taxation purposes, too. The analyses refer either to confidential tax data (Eberhartinger and Klostermann 2007) or to publicly available data for the year preceding the first-time adoption of IFRS (Gavana, Guggiola, and Marenzi 2010) or to computer-based program simulating the lifecycle of a typical firm (Jacobs et al. 2005; Haverals 2007; Oestreicher and Spengel 2007).

The economic logic behind the decision by policy makers, whether to allow the usage of IFRS for taxation, refers to the (modified) concept of comparative advantages originally introduced by (Ricardo 1817). This institute may be relevant especially for small open economies, such as the Czech Republic. The Czech Republic is a small open economy with a significant share (around $40 \%$ ) of foreign capital on the ownership of Czech-domiciled companies. The ownership structure reduces an ability of public authorities to collect corporate income taxes in required amount effectively. Companies under foreign control can enter with other companies within the group into transfer pricing (Gordon and MacKieMason 1995) and licencing (Heckemeyer and Overesch 2013) in order to shift profit outside the local tax jurisdiction. Any negative change in tax policy can induce a departure of foreign investors (Razin and Sadka 1991; Fuest, Huber, and Mintz 2005) and thus result in a crush of tax collection.

On the other hand, any profit shifting is always connected with increased administrative burden of an optimising company (Alley and James 2005). The introduction of IFRS as tax basis can thus attract companies in many ways. It can mitigate their willingness to profit shifting from domestic companies outside the country, as a material difference in tax base in favour of IFRS can occur. In addition, the shift to 
IFRS can encourage profit shifting from foreign entities into the country, as the taxation system is more transparent and predictable. Dinkel, Keller, and Schanz (2014) showed on a sample of German parent companies that optimal tax structures were created by establishing of new subsidiaries in foreign countries with favourable tax regime. This may bring some benefits for a small open economy. However, Spengel et al. (2012) investigated that introduction of IFRS as a tax basis could lead to the change in the effective tax rate, as the definition of taxable income and its conformity with accounting income is blurred.

The provisions of Regulation (EC) 1606/2002 were incorporated in the Act No. 563/1991, on accounting. The obligation to prepare consolidated financial statements according to the International Accounting Standards (as adopted by the EU) by companies listed on the EU capital markets is included in §23a, Article 1. However, the Czech regulator went a step further and set up a duty for listed companies to prepare their individual financial statements according to the IFRS, too. However, pursuant $\S 23$, Article 2 of Act 586/1992, on income taxes "the determining of the tax base is based on the accounting income, always without the influence of international accounting standards .... A taxpayer, who prepares its statutory financial statements in accordance with International Accounting Standards, as approved by the European Union, shall determine its accounting income for the purposes of this Act with reference to specific legal act".

Act on accounting, which governs financial reporting in compliance with the Czech Accounting Standards, is referred to by the Act on income taxes, when dealing with calculation of tax base. It could be therefore concluded that IFRS are not relevant for tax purposes at all, even though they are applied in statutory individual financial statements, e.g. by Czech listed companies. All Czech companies have to apply Czech GAAP in order to compute an accounting profit, which is relevant for filling-in the tax returns. This obligation is in force also for companies listed on EU stock exchange, even though they must use the IFRS for their statutory individual financial statements. Additional (complex) evidence is thus needed to comply with tax duties.

The fact that all corporate taxpayers use the same accounting principles for taxation brings benefits esp. to tax authorities. Theoretically, supervision over all types of entities can be processed in the same pattern, as entities uses the same accounting and tax rules, as they fill-in the same tax form, etc. However, the reality is not so simple. 
Regulatory framework does not encompass any binding method, which has to be followed by listed companies. Therefore, listed companies chose among variety of procedures, how to compute accounting income according to Czech GAAP for the purpose of tax filling. E.g. they use supplementary evidence in data spreadsheets, make notes on accounting documents or keep two sets of books within their accounting software. Regardless which method is employed, tax supervisor is always challenged to assess, whether the conversion of IFRS individual financial statements (used by listed companies for statutory purposes) to Czech statements (used for taxation purposes) is complete and accurate.

Regarding checking the correctness of financial statements conversion by listed companies for accounting income calculation used as basis for the tax base, accounting transactions can be split up into four groups:

- transactions occurring only in IFRS statements;

- transactions occurring both in IFRS and Czech GAAP statements, but differently classified and/or measured;

- transactions occurring both in IFRS and Czech GAAP statements, with same classification and measurement;

- transactions occurring only in Czech GAAP statements.

Tax officers can check first three types of transactions easily, as they are posted directly in accounting software, which keeps transactions in compliance with IFRS of course. If these are accompanied with corresponding documents, possible differences can be analysed quickly with reference to distinct provisions in Czech GAAP compared to IFRS. On the other hand, the last group of transactions is not included at accounting system of a listed company at all, as they cannot be shown under IFRS statements. However, this type of transactions is important for the calculation of tax base. There are no accounting records; there could be no underlying documents. During tax base computation, these transactions could be omitted (either intentionally or unintentionally). Is the tax authority able to reveal such omissions? The answer is yes, but it is not an easy job to do. A detailed knowledge of the differences between Czech GAAP and IFRS is then inevitable. In addition, tax officers have to possess some kind of forensic skills to uncover all omissions, mistakes and evasions caused by a wrong conversion from IFRS to Czech GAAP.

To summarise, the current system does not bring any presumed advantages for tax authorities. Furthermore, necessary double evidence by certain entities elicits additional administrative costs, which usefulness 
from macroeconomic point of view is doubtful. The only advantage of current status quo is that it preserves an equal access of state to all taxpayers (MacDonald 2002; Oestreicher and Spengel 2007). However, the Czech Republic is a typical example of a country with hybrid system, where government uses not only tax law, but also accounting rules to influence and thus to ease the tax collection (Ištvánfyová, Mejzlík, and Pelák 2010). This approach produces high costs both on corporate and national economy level, which surely outweigh benefits of state institutions starving for the retention of control over tax system and predictable tax collection.

Unsatisfactory shape of taxation system in the Czech Republic seems to be resolvable apparently by a change in Act on income taxes by allowing IFRS to be basis also for the calculation of tax base. It means that accounting profit from statutory accounts, whatever set of principle is used, should serve as the starting point for income tax calculation. A considerable number of advantages for companies can emerge. Furthermore, a taxation based on IFRS may attract internationally operating holdings to place their subsidiaries or even headquarters, as this kind of relation between accounting and taxation is more transparent than being based on local GAAP. However, before any fundamental change, an appropriate analysis of possible opportunities and risks shall be performed. Following cardinal issues shall be addressed:

- Q1: Is the topic relevant at all? Is corporate income tax an important source of tax revenues?

- Q2: Are entities with statutory IFRS statements significant in terms of income taxes?

- Q3: If IFRS are allowed for income tax calculation, which level of income shall be used? Should it be Profit \& loss, or comprehensive income?

- Q4: Are any important differences in profit \& loss between Czech GAAP and IFRS? 


\section{Data, Results and Discussion}

For answering the research questions raised in previous chapter, both macro- and microeconomic data are needed. Macroeconomic dataset capturing the development of gross domestic product (GDP), total tax revenues, and tax revenues from corporate income taxes is retrieved from national accounts administrated by the Czech Statistical Office. Microeconomic data on financial figures of the IFRS entities were extracted manually and directly from corresponding individual financial statements.

\section{Tab. 1: Share of corporate income taxes on total tax revenues and GDP}

\begin{tabular}{lrrrrrr}
\hline \multicolumn{1}{c}{ Year } & $\mathbf{1 9 9 5}$ & $\mathbf{1 9 9 6}$ & $\mathbf{1 9 9 7}$ & $\mathbf{1 9 9 8}$ & $\mathbf{1 9 9 9}$ & $\mathbf{2 0 0 0}$ \\
\hline \hline Tax rate & $41 \%$ & $39 \%$ & $39 \%$ & $35 \%$ & $35 \%$ & $31 \%$ \\
CIT (millions CZK) & 67,255 & 56,510 & 69,357 & 67,464 & 79,458 & 75,155 \\
Share on tax revenues (\%) & $12.3 \%$ & $9.4 \%$ & $10.6 \%$ & $9.8 \%$ & $10.8 \%$ & $9.8 \%$ \\
Share on GDP (\%) & $4.4 \%$ & $3.2 \%$ & $3.7 \%$ & $3.3 \%$ & $3.7 \%$ & $3.3 \%$ \\
\hline \multicolumn{1}{c}{ Year } & $\mathbf{2 0 0 1}$ & $\mathbf{2 0 0 2}$ & $\mathbf{2 0 0 3}$ & $\mathbf{2 0 0 4}$ & $\mathbf{2 0 0 5}$ & $\mathbf{2 0 0 6}$ \\
\hline \hline Tax rate & $31 \%$ & $31 \%$ & $31 \%$ & $28 \%$ & $26 \%$ & $24 \%$ \\
CIT (millions CZK) & 94,393 & 106,731 & 118,882 & 128,665 & 134,909 & 153,627 \\
Share on tax revenues (\%) & $11.4 \%$ & $12.0 \%$ & $12.5 \%$ & $12.2 \%$ & $12.1 \%$ & $13.0 \%$ \\
Share on GDP $(\%)$ & $3.9 \%$ & $4.2 \%$ & $4.4 \%$ & $4.4 \%$ & $4.3 \%$ & $4.6 \%$ \\
\hline \hline \multicolumn{1}{c}{ Year } & $\mathbf{2 0 0 7}$ & $\mathbf{2 0 0 8}$ & $\mathbf{2 0 0 9}$ & $\mathbf{2 0 1 0}$ & $\mathbf{2 0 1 1}$ & $\mathbf{2 0 1 2}$ \\
\hline \hline Tax rate & $24 \%$ & $21 \%$ & $20 \%$ & $19 \%$ & $19 \%$ & $19 \%$ \\
CIT (millions CZK) & 171,071 & 161,948 & 132,327 & 131,710 & 129,031 & 127,371 \\
Share on tax revenues (\%) & $12.2 \%$ & $12.2 \%$ & $10.5 \%$ & $10.3 \%$ & $9.7 \%$ & $9.5 \%$ \\
Share on GDP $(\%)$ & $4.7 \%$ & $4.2 \%$ & $3.5 \%$ & $3.5 \%$ & $3.4 \%$ & $3.3 \%$ \\
\hline \hline
\end{tabular}

Source: Authorial calculation using data published by the Czech Statistical Office (CSO) http://apl.czso.cz/pll/rocenka/rocenkavyber.gov_s?mylang=CZ.

Tab. 1 elucidates a possible answer to Question 1 about the importance of corporate income tax on total tax revenues of the Czech Republic. Despite the steep reduction in tax rate (from $41 \%$ in year 1995 to $19 \%$ in year 2012), the relative share of corporate income tax on total tax revenues (including social security) remains stable; $11.2 \%$ on average. A decrease 
in last three years can be attributed to an economic downturn. Corporate income tax is not the most important tax of the Czech taxation systems; however, it forms a significant source of financing public expenditures. A change in design of corporate income tax system therefore may influence tax collection significantly from the perspective of public budgets.

The empirical testing of the next two issues requires data from individual financial statements of those entities, which report under the IFRS regime. An empirical analysis is performed for years 2010 and 2011, for which two sets of data are available. Firstly, the development of total revenues from corporate income tax is used. Secondly, there was extracted information about profits and taxation from financial statements of those entities, which apply IFRS as accounting principles in their statutory individual financial statements. There were selected all those companies, which prepared their statutory individual financial statements in compliance with IFRS, i.e.:

- companies listed on the Prague Stock Exchange (further "PSE");

- companies, which opted to use IFRS on voluntary basis.

There were listed 46 corporate issuers on PSE during the analysed years, from which 33 have legal and therefore tax domicile in the Czech Republic. Remaining 13 issuers are foreign domiciled. However, in six cases, their primary economic environment is and original legal domicile was the Czech Republic. These emitters decided to move their legal domiciles to "tax havens". In order to investigate homogenous sample, additional five entities were excluded from the analysis. To conclude, 28 issuers listed on PSE entered the analysis. Furthermore, two companies used the option to apply IFRS voluntarily. Therefore, the sample encompasses 30 entities in total.

An issue raised by Question 2 can be assessed using data in Tab. 2 . From financial statements of analysed companies, data on current income tax expense were extracted manually and it was related to total tax collection of corporate income taxes. The share is about $17 \%$, which is not decisive, but also not immaterial. A rapid growth of number of companies reporting under IFRS cannot be excluded, if it shows to be favourable. Recalling the IFRS option, it has to be mentioned that parent companies listed on PSE control 334 Czech subsidiaries in total. All these companies can shift to IFRS in their individual financial statements voluntarily pursuant $\S 19 \mathrm{a}$, article 7 and 8 , as they are consolidated under IFRS regime. Moreover, there is a significant number of other Czech 
companies, which are subject of IFRS consolidation (as they are under control of foreign parent companies, which are listed on other EU stock exchanges). The estimates of companies eligible for the IFRS option differ, ranging from 2000 (estimate of the Ministry of Finance) to 200,000 (number of companies under foreign control according to the statistics of the CSO) companies.

\section{Tab. 2: Share of corporate income taxes by IFRS entities on total corporate taxes}

\begin{tabular}{lrr}
\multicolumn{1}{c}{ Year } & \multicolumn{1}{c}{$\mathbf{2 0 1 0}$} & $\mathbf{2 0 1 1}$ \\
\hline \hline CIT IFRS entities (millions CZK) & 20994 & 22957 \\
CIT all entities (millions CZK) & 127404 & 128789 \\
Share (\%) & $16.5 \%$ & $17.8 \%$ \\
\hline \hline
\end{tabular}

Source: Authorial calculation using data published by the CSO and data from companies' financial statements.

Question 3 raises the issue whether, provided that IFRS were allowed for taxation, profit and loss or comprehensive income should be the basis for taxable profits. Alternatively, the Question scrutinised whether other comprehensive income (further "OCI") is a material performance measure of Czech companies and whether it should be included or excluded from taxation. In present, Czech GAAP does not recognise other comprehensive income in financial statements. There are some differences compared to IFRS in terms of other comprehensive income:

- certain items are not applied in Czech accounting at all (revaluation model under IAS 16 and IAS 38);

- certain items are recognised directly in equity (cash flow hedge, available-for-sale instruments);

- actuarial gains and losses are not dealt explicitly by Czech GAAP, but according to general principles in Act on accounting they shall be classified in profit $\&$ loss.

The resulting impact on taxation is unclear, as there can be all types of movements of OCI components, which might be or might not be displayed in Czech financial statements. 
Procházka, D.: The IFRS as Tax Base: Potential Impact on a Small Open Economy.

Tab. 3: Aggregate value of total comprehensive income

\begin{tabular}{|c|c|c|c|c|c|c|}
\hline Comp. & P\&L 2011 & CI 2011 & P\&L 2010 & CI 2010 & $\begin{array}{c}\text { OCI } 2011 \\
\%\end{array}$ & $\begin{array}{c}\text { OCI } 2010 \\
\%\end{array}$ \\
\hline 1 & $1,392,529$ & $1,133,437$ & 678,087 & 388,982 & $-22.86 \%$ & $-74.32 \%$ \\
\hline 2 & $-261,985$ & $-223,115$ & $-351,649$ & $-348,529$ & $-17.42 \%$ & $-0.90 \%$ \\
\hline 3 & $37,337,000$ & $29,543,000$ & $34,762,000$ & $40,058,000$ & $-26.38 \%$ & $13.22 \%$ \\
\hline 4 & $4,158,000$ & $2,100,000$ & $11,860,000$ & $10,699,000$ & $-98.00 \%$ & $-10.85 \%$ \\
\hline 5 & $18,316,000$ & $15,078,000$ & $14,317,000$ & $11,992,000$ & $-21.47 \%$ & $-19.39 \%$ \\
\hline 6 & $11,148,000$ & $5,627,000$ & $13,572,000$ & $14,688,000$ & $-98.12 \%$ & $7.60 \%$ \\
\hline 7 & $2,397,874$ & $1,900,682$ & $5,566,785$ & $5,155,523$ & $-26.16 \%$ & $-7.98 \%$ \\
\hline 8 & 171,559 & 133,079 & 114,353 & 107,310 & $-28.92 \%$ & $-6.56 \%$ \\
\hline 9 & $2,531,110$ & $2,531,110$ & 60,236 & 60,236 & $0.00 \%$ & $0.00 \%$ \\
\hline 10 & $3,253,000$ & $2,631,000$ & $2,288,000$ & $1,845,000$ & $-23.64 \%$ & $-24.01 \%$ \\
\hline 11 & $2,851,830$ & $2,223,017$ & $2,319,712$ & $1,821,454$ & $-28.29 \%$ & $-27.35 \%$ \\
\hline 12 & $1,334,000$ & $3,287,000$ & $3,473,000$ & $2,251,000$ & $59.42 \%$ & $-54.29 \%$ \\
\hline 13 & $9,380,000$ & $14,234,000$ & $14,417,000$ & $12,769,000$ & $34.10 \%$ & $-12.91 \%$ \\
\hline 14 & 346,000 & 300,000 & 271,000 & 254,000 & $-15.33 \%$ & $-6.69 \%$ \\
\hline 15 & 38,477 & 6,135 & 75,063 & 75,063 & $-527.17 \%$ & $0.00 \%$ \\
\hline 16 & $-2,849$ & $-2,849$ & 16,188 & 16,188 & $0.00 \%$ & $0.00 \%$ \\
\hline 17 & 4,107 & 4,107 & 37,375 & 37,375 & $0.00 \%$ & $0.00 \%$ \\
\hline 18 & $2,543,000$ & $2,543,000$ & $2,427,000$ & $2,427,000$ & $0.00 \%$ & $0.00 \%$ \\
\hline 19 & 82,611 & 82,611 & 98,144 & 98,144 & $0.00 \%$ & $0.00 \%$ \\
\hline 20 & $1,010,050$ & $1,010,050$ & $1,682,870$ & $1,682,870$ & $0.00 \%$ & $0.00 \%$ \\
\hline 21 & 362,480 & 362,480 & 352,814 & 352,814 & $0.00 \%$ & $0.00 \%$ \\
\hline 22 & 186,061 & 186,061 & 130,084 & 130,084 & $0.00 \%$ & $0.00 \%$ \\
\hline 23 & $7,648,000$ & $7,648,000$ & $12,696,000$ & $12,696,000$ & $0.00 \%$ & $0.00 \%$ \\
\hline 24 & 52,503 & 52,297 & 31,889 & 31,652 & $-0.39 \%$ & $-0.75 \%$ \\
\hline 25 & 256,551 & 256,551 & 512,121 & 512,121 & $0.00 \%$ & $0.00 \%$ \\
\hline
\end{tabular}




\begin{tabular}{rrrrrrr}
\hline \hline Comp. & P\&L 2011 & CI 2011 & P\&L 2010 & CI 2010 & $\begin{array}{c}\text { OCI 2011 } \\
\text { \% }\end{array}$ & $\begin{array}{c}\text { OCI 2010 } \\
\text { \% }\end{array}$ \\
\hline \hline 26 & 791,468 & 791,468 & $1,030,207$ & $1,030,207$ & $0.00 \%$ & $0.00 \%$ \\
\hline 27 & $-1,165$ & $-1,165$ & $-2,646$ & $-2,646$ & $0.00 \%$ & $0.00 \%$ \\
\hline 28 & 244,987 & 244,987 & 268,832 & 268,832 & $0.00 \%$ & $0.00 \%$ \\
\hline 29 & $14,288,000$ & $9,427,000$ & $9,404,000$ & $8,797,000$ & $-51.56 \%$ & $-6.90 \%$ \\
\hline 30 & 114,083 & 114,083 & N/A & N/A & $0.00 \%$ & N/A \\
\hline \hline
\end{tabular}

Source: Authorial calculation using data from companies' financial statements Note: The list of companies can be found in appendix.

Tab. 3 shows profit and loss, comprehensive income and the relative share of other comprehensive income on total comprehensive income for both analysed years. For year 2011, other comprehensive income is zero (i.e. OCI contains no items) in 14 out of 30 cases. In year 2010, a similar situation happened in 14 out of 29 cases. Financial institutions report the most of cases of non-zero OCI, which corresponds to intuitive expectations (as financial institutions deal in financial instruments, which changes in value is reported under OCI under certain conditions). However, six cases of non-zero OCI appears by non-financial entities. Moreover, two biggest Czech companies (Škoda Auto; ČEZ) report a significant amount of OCI not only in relative, but also in absolute terms. If IFRS are allowed for taxation, the question, whether to apply tax rate on profit \& loss or on comprehensive income, have to be addressed in advance, as OCI is a material item by half of "IFRS companies".

Question 4 captures a crucial issue in all deliberations about allowing IFRS to be relevant for tax base. Four possible approaches can be utilised:

- a qualitative analysis of differences between IFRS and Czech GAAP;

- a model of generalised equations, which will encompass benefits and costs for each party under current situation compared to conditions after switch to IFRS;

- an empirical model of Spengel et al. (2012) in the individualised version of Roggeman et al. (2014);

- a quantitative analysis of differences between Czech GAAP and IFRS profit \& loss figures actually reported by Czech companies, which could be done as follows: 
- by analysing publicly available financial statements for the period of the first IFRS implementation (pairing of comparative information based on IFRS with Czech GAAP statements published a period earlier);

- by extracting needed data from tax returns in periods following the first implementation.

The crucial limitation is a public unavailability of tax returns. A proper proxy measure, which would substitute needed individual tax data, should be explored. Alternatively, a survey among IFRS entities may be underwent to obtain data directly from companies on anonymous basis.

\section{Conclusion}

Allowing IFRS for the tax purposes may be an acceptable political choice, how to face to an increasing pressure from foreign owners of Czech companies to be allowed:

- to prepare financial statements in compliance with IFRS solely;

- to use statutory accounts also for income tax calculation because of higher understandability and transparency of IFRS compared to Czech GAAP.

The first issue has been already fulfilled by amending the Act on accounting effective from 2011, which offers an IFRS option in statutory individual financial statements for those companies, which are consolidated under IFRS regime. The second claim addresses a need to have not only comparable and transparent accounting, but also taxation rules, e.g. by allowing particular companies to apply IFRS in their tax returns. The process is not about the question whether "yes or no", but rather an issue of "when". An empirical study on the population of Czech companies reporting under the IFRS in their individual statements showed that these companies create around $17 \%$ of income tax revenues. The IFRS option embedded in the Act on accounting may substantially affects the tax collection, if the IFRS were permitted for taxation purposes.

The benefits and costs of "what would happen, if IFRS were a tax base" can be found in some EU countries. E.g. Slovakia enables companies, preparing statutory statements in compliance with IFRS, to decide, whether their tax filling will refer to local GAAP or IFRS. The 
switch to a new system of taxation may generate one-time effects. Some countries prefer an inclusion of these transition costs/revenues into the tax base in the year of transitions (e.g. Slovakia and Iceland); other countries allow spreading the effects over a longer period (e.g. Ireland over 5 years and Luxemburg over 2-5 years). Even if IFRS remain irrelevant for taxation, tax officers shall be trained to gain knowledge of IFRS principles. As soon as IFRS are applied by accounting entities, tax authorities have to be able to check the correctness of conversion to local GAAP.

Based on previous reasoning, a proposal permitting the IFRS to be tax relevant is justifiable at least from companies' point of view. Allowing "IFRS companies" to derive their income tax duty with reference to the IFRS pre-tax income may not only reduce costs relating to the financial statement conversion, but it may have additional positive benefits on macroeconomic level, too. As a small open economy with a decisive share of foreign capital on the company's ownership, the Czech Republic may benefit from this step by increasing understandability and transparency of taxation system in its relation to accounting. The IFRS are worldwide expected and their major principles are well known. In addition, the IFRS are published by a body, which is independent of national governments. From this point of view, a level of state discretion in income tax system is supposed to be reduced (Morais and Curto 2009) and investors can expect a higher transparency, stability and predictability of future influences on their current tax expenses. Taxation based (fully or partly) on the IFRS in combination with other favourable conditions may attract foreign investors to open new facilities in the Czech Republic, or even to shift some current operations there (including domicile of the group).

While implementing the IFRS, national states lose power to control effectively the collection of taxes in order to meet their fiscal needs. As the IFRS are published for the purposes of capital markets and investors in their decision-making, they do not address tax issues. A single change in whatever standard may lead to an extreme variance in accounting profits and thus in tax collection. This is a severe risk, which arises in the connection with allowing the IFRS to be a tax base. A preliminary analysis performed that "IFRS companies" generate significant part of income tax revenues, with possibility of sharp increase of the share, if IFRS option is utilised by eligible non-listed companies defined by Czech Act on accounting. 
Procházka, D.: The IFRS as Tax Base: Potential Impact on a Small Open Economy.

\section{References}

Alley, C. - Simon, J. (2005): The Interface between Financial Accounting and Tax Accounting: A Summary of Current Research. Working Paper Series University of Waikato, no. 84.

Dinkel, A. - Keller, S., - Schanz, D. K. (2014): Tax Attractiveness and the Location of German-Controlled Subsidiaries. SSRN Electronic Journal. <http://www.ssrn.com/abstract=2408432>

Eberhartinger, E. - Klostermann, M. (2007): What If IFRS Were a Tax Base? New Empirical Evidence from an Austrian Perspective. Accounting in Europe, vol. 4, no. 2, pp. 141-168.

Fuest, C. - Huber, B. - Mintz, J. (2005): Capital Mobility and Tax Competition. Foundations and Trends ${ }^{\circledR}$ in Microeconomics, vol. 1, no. 1, pp. 1-62.

Gavana, G. - Guggiola, G. - Marenzi, A. (2010): Tax Impact of International Financial Reporting Standards: Evidence from a Sample of Italian. Working Paper Series Università Degli Studi dell'Insubria. $<$ http://arca.unive.it/bitstream/10278/39026/1/Gavana_Guggiola_Marenzi \%20WP2.pdf>

Gordon, R. H. - MacKie-Mason, J. K. (1995): Why Is There Corporate Taxation in a Small Open Economy? The Role of Transfer Pricing and Income Shifting. In: Feldstein, M. S. - Hines, J. R. - Hubbard, R. G. (ed.): The Effects of Taxation on Multinational Corporations. Chicago: University of Chicago Press, pp. 67-94, 1995.

Haverals, J. (2007): IAS/IFRS in Belgium: Quantitative Analysis of the Impact on the Tax Burden of Companies. Journal of International Accounting, Auditing and Taxation, vol. 16, no. 1, pp. 69-89.

Heckemeyer, J. H. - Overesch, M. (2013): Multinationals' Profit Response to Tax Differentials: Effect Size and Shifting Channels. Discussion Paper No. 13-045. ZEW, Zentrum für Europäische Wirtschaftsforschung.

Ištvánfyová, J. - Mejzlík, L. - Pelák, J. (2010): Progression of Financial Reporting in Czech Republic and Its Regulation. European Financial and Accounting Journal, vol. 6, no.1, pp. 64-77.

Jacobs, O. H. - Spengel, C. - Stetter, T. - Wendt, C. (2005): EU Company Taxation in Case of a Common Tax Base. Discussion Paper No. 05-037. ZEW, Zentrum für Europäische Wirtschaftsforschung. 
MacDonald, G. (2002): The Taxation of Business Income: Aligning Taxable Income with Accounting Income Macdonald. TLRC Discussion Paper No. 2. The Institute for Fiscal Studies. <http://www.ifs.org.uk/comms/dp2.pdf>

Morais, A. I. - Curto, J. D. (2009): Mandatory Adoption of IASB Standards: Value Relevance and Country-Specific Factors. Australian Accounting Review, vol. 19, no. 2, pp. 128-143.

Oestreicher, A. - Spengel, C. (2007): Tax Harmonisation in Europe: The Determination of Corporate Taxable Income in the EU Member States. ZEW Discussion Papers. Discussion Paper No. 07-035. ZEW, Zentrum für Europäische Wirtschaftsforschung.

Procházka, D. - Procházková Ilinitchi, C. (2011): The Theoretical Relationships among Foreign Direct Investments, Migration and IFRS Adoption. European Financial and Accounting Journal, vol. 6, no. 4, pp. 85-100.

Razin, A. - Sadka, E. (1991): International Tax Competition and Gains from Tax Harmonization. 3152. NBER Working Papers. National Bureau of Economic Research. <http://www.nber.org/papers/w3152.pdf>

Ricardo, D. (1817): On the Principles of Political Economy and Taxation. London: John Murray.

<http://www.econlib.org/library/Ricardo/ricP.html>

Roggeman, A. I. V. P. V. C. - Coppens, C. (2014): Impact of a Common Corporate Tax Base on the Effective Tax Burden in Belgium. Journal of Business Economics and Management, vol. 15, no. 3, pp. 530-543.

Spengel, C. - Ortmann-Babel, M. - Zinn, B. - Matenaer, S. (2012): A Common Corporate Tax Base for Europe: An Impact Assessment of the Draft Council Directive on a CC(C)TB. Discussion Paper No. 12-039. ZEW, Zentrum für Europäische Wirtschaftsforschung. 


\section{Appendix A: List of companies}

\begin{tabular}{clc}
\hline No. & \multicolumn{1}{c}{ Company } & FI \\
\hline 1 & CETELEM ČR & yes \\
\hline 2 & CPI & no \\
\hline 3 & ČEZ & no \\
\hline 4 & Česká pojišt'ovna & yes \\
\hline 5 & Česká spořitelna & yes \\
\hline 6 & ČSOB & yes \\
\hline 7 & Dalkia & no \\
\hline 8 & Energoaqua & no \\
\hline 9 & GREENVALE & no \\
\hline 10 & Hypoteční banka & yes \\
\hline 11 & Raiffeisenbank & yes \\
\hline 12 & UniCredit Bank & yes \\
\hline 13 & Komerční banka & yes \\
\hline 14 & Sberbank CZ & yes \\
\hline 15 & Wüstenrot & yes \\
\hline 16 & ISTROKAPITAL & yes \\
\hline 17 & Jáchymov Property Management & no \\
\hline 18 & Philip Morris & no \\
\hline 19 & Pražské služby & no \\
\hline 20 & SM plynárenská & no \\
\hline 21 & SMVaK Ostrava & no \\
\hline 22 & Spolek pro chemickou a hutní výrobu & no \\
\hline 23 & Telefónica & no \\
\hline 24 & TOMA & no \\
\hline 25 & UNIPETROL & no \\
\hline 26 & Východočeská plynárenská & no \\
\hline 27 & VET ASSETS & no \\
\hline 28 & Wüstenrot & yes \\
\hline 29 & Škoda AUTO & no \\
\hline 30 & Tamero invest & \\
\hline & & \\
\hline
\end{tabular}

Note: FI - financial institution. 


\title{
The IFRS as Tax Base: Potential Impact on a Small Open Economy
}

\begin{abstract}
The IFRS adoption has improved the quality of accounting information significantly. However, huge costs are incurred by all subjects involved. The process has considerable consequences for tax systems, too. State authorities are solving how to ensure the control over tax duty fulfilment under a new financial reporting system. As corporate income tax systems in code law countries are tightly bound up with accounting regulation, governments are forced to decide whether and in which way companies preparing financial statements under the IFRS shall reflect the IFRS based figures in their income tax returns. The paper focuses on specifics of a small open economy, such as the Czech Republic. Four cardinal research issues are identified, if the eligibility of the IFRS as a tax base is ruminated on. Three issues are already assessed with the reference to publicly available data; the last one needs further scrutiny, as non-public data from tax returns are needed for the analysis.
\end{abstract}

Key words: IFRS; Taxation; Small open economy.

JEL classification: M41, H25 